JINOTEP Vol (6) No.1 (2019): 39-44

JINOTEP (Jurnal Inovasi Teknologi Pembelajaran):

Kajian dan Riset Dalam Teknologi Pembelajaran

http://journal2.um.ac.id/index.php/jinotep/index

\title{
PENGGUNAAN GAME EDUKASI DIGITAL SEBAGAI SARANA PEMBELAJARAN ANAK USIA DINI
}

\author{
Andri Setiawan, Henry Praherdhiono, Sulthoni
}

Universitas Negeri Malang - Malang Indonesia

\begin{tabular}{l} 
Article History \\
\hline Received: April 25, 2019 \\
Accepted: May 25,.2019 \\
Published:July 16, 2019 \\
\hline Keywords \\
\hline Game Edukasi Digital, \\
Digital Game, Anak \\
Usia Dini, Lingkungan \\
Virtual \\
\hline
\end{tabular}

\begin{abstract}
Abstrak
Perkembangan dan dukungan teknologi digital telah memberikan peluang baru untuk memberikan pembelajaran dalam bentuk game edukasi digital pada anak usia dini. Karena anak-anak sangat terkait dengan permainan, maka game edukasi digital menjadi langkah strategis untuk memberikan pengalaman baru pembelajaran. Penelitian ini menggunakan pendekatan literature review untuk menganalisis secara komprehensif dari artikel yang dipublikasikan sejak tahun 2013 hingga 2018. Temuan penelitian ini mengungkapkan sebagaian besar artikel fokus dalam mengembangakan game edukasi digital sebagai alat pembelajaran anak usia dini. Metode experiment dan survei ditemukan menjadi metode utama dari sebagian besar artikel untuk mengetahui efektifitas penggunaan game edukasi digital pada pembelajaran anak usia dini dalam berbagai subjek pembelajaran.
\end{abstract}

\begin{abstract}
The development and support of digital technology has provided new opportunities to provide learning in the form of digital educational games for early childhood. Because children are very related to games, digital education games are a strategic step to provide new learning. This study uses a review literature reference to analyze articles published from 2013 to 2018. The findings of this study reveal that a large article focuses on developing digital education games as learning tools for early childhood. Experimental methods and surveys were found to be the main method of most articles to learn the effectiveness of using digital educational games for learning early childhood in various lessons.
\end{abstract}

Corresponding author :

Adress: Jl. Trowulan GG IV No. 14 Kec. Sananwetan Kel. Bendogerit

2019 Universitas Negeri Malang p-ISSN 2406-8780

Kota Blitar Jawa Timur Indonesia e-ISSN 2654-7953

Instansi: Universitas Negeri Malang

E-mail: andrisetiawan640@gmail.com 
40 JINOTEP (Jurnal Inovasi dan Teknologi Pembelajaran): Kajian dan Riset Dalam Teknologi Pembelajaran Vol 6, No. 1, Oktober 2019, Hal. 39-44

\section{PENDAHULUAN}

Saat ini, game digital menjadi bagian dari aktivitas kehidupan seseorang. Dukungan teknologi teknologi seluler dan komputer telah membawa game digital sebagai salah satu alat pembelajaran. Kaitannya dengan pembelajaran, game digital tidak hanya menghadirkan kegiatan yang immersive dan menyenangkan, melainkan kegiatan yang terkait dengan konten pembelajaran untuk mencapai tujuan tertentu. Sebagai alat pembelajaran game digital telah mengalami transformasi menjadi game edukasi digital. Game ini memberikan peluang terhadap pebelajar untuk mengembangkan keterampilan, pengetahuan dan sikap melalui prinsip dan fitur yang digunakan di dalam game play (Nikiforidou, 2018). Khususnya pada anakanak, game edukasi digital memberi kesempatan untuk mengalami representasi virtual dan lingkungan kreatif (Edwards, 2013). Hal ini dapat memperluas pengalaman anak melalui game dalam keterlibatan aktif yang telah di skenariokan untuk tujuan pembelajaran. Interaksi anak-anak dengan game digital melalui gambar, simbol, suara, gerakan, kata sederhana, avatar dan lingkungan virtual memungkinkan menumbuhkan ketertarikan dan mendukung untuk membangun konsep serta proses kognitif secara keberlanjutan (Nikiforidou, 2018).

Anak usia dini sangat terkait dengan pembelajaran yang dikemas di dalam permainan. Pembelajaran pada usia ini, menekankan bahwa anak-anak memperoleh beberapa keterampilan melalui permainan (Akman \& Guchan, 2015). Sehingga, penggunaan game edukasi digital memberikan pengalaman pembelajaran interaktif, menyenangkan dan interaksi sosial sesuai kebutuhan perkembangannya. Pertama, anak-anak membutuhkan rangsangan untuk mengembangkan keterampilan motorik halus sebelum menuju pada ranah kognitif. Anak-anak dapat berinteraksi seperti menyentuh layar atau menekan tombol, kemudian belajar keterampilan seperti memahami aturan sederhana atau membuat pilihan. Penggunaan game ini dapat memperluas imajinasi dan pengalaman anak, menciptakan solusi, membangun pengetahan dan membangun budaya bermain digital sesuai dengan perkembangannya.

Penelitian ini menyajikan literature review untuk mengkaji perkembangan game edukasi digital untuk anak usia dini yang diawali pada tahun 2013. data artikel dikumpulkan dari basis data Association for Computing Machinery (ACM), SpringerLink dan IEEE Explore Digital Library. Kemudian artikel ditinjau sesuai dengan topik yang dipilih. Artikel publikasi yang didapatkan akan diseleksi berdasarkan kriteria artikel yang dapat digunakan sebagai literature review. Berkaitan dengan penelitian, selanjutnya memaparkan hasil survei literatur dan membahas temuan-temuan dari survei literatur.

\section{Game Edukasi Digital (Digital Game Based Learning)}

Game edukasi digital merupakan pembelajaran yang terjadi dengan berbantuan game digital. Sehingga, belajar dan pengajaran sangat berhubungan dengan penggunaan game. Terdapat dua pandangan dari game edukasi digital ini, yakni pertama pendangan dari pebelajar untuk mempertimbangkan bagaimana seseorang dapat belajar dari game dan pandangan kedua dari pengajar tentang bagaimana dapat mengajar menggunakan game (Becker, 2017). Menurut becker, hal ini dapat digambarkan seperti lambang Yin Yang (Lihat Gambar. 1).

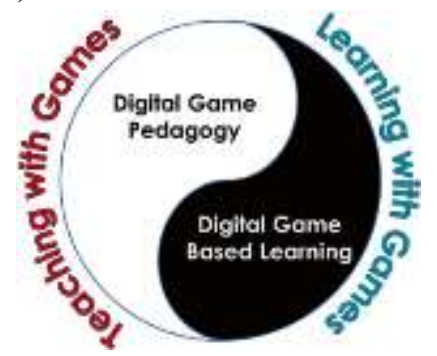

Gambar 1. Hubungan antara game edukasi dan pedagogy

Gambar tersebut menunjukksn bahwa antara unsur belajar dan mengajar merupakan unsur yang saling melengkapi dan saling mendukung. Dengan demikian, Game edukasi digital bertujuan untuk memperoleh pengetahuan, menumbuhkan kebiasaan dan menumbuhkan pemahaman yang di kemas dalam lingkungan digital (Nikiforidou, 2018). Terdapat empat jenis 
pembelajaran melalui game edukasi digital yakni pembelajaran berbasis konten seperti matematika, keterampilan khusus seperti mendongeng, keterampilan sistematis dan membuat suatu konten seperti membuat video (Klopfer., Osterweil.,Salen, 2009).

\section{Game Edukasi Digital Pada Anak Usia Dini}

Anak usia dini dengan umur 0 sampai 6 tahun merupakan dasar untuk perkembangan pembelajaran seumur hidunya. Peran pendidikan disini sangat penting untuk mempromosikan perkembangan intelektual anak yang lebih baik. Khususnya anak usia dini, bermain adalah cara alami anak-anak untuk meningkatkan dan mengembangkan keterampilannya, karena saat bermain mereka menggunakan banyak indera untuk menangkap dan memperoleh beragam informasi dan memperluas pengetahuan mereka serta belajar tentang jati dirinya (Lamrani., Abdelwed., Charaibi., Qassimi., Hafidi, 2018). Melalui bermain anak-anak dapat memilih dan membangun kegiatan mereka sendiri dalam melakukan sesuatu. Sehingga, game edukasi digital memberi peluang besar untuk anak-anak memberikan pengalaman dan mengembangkan keterampilan abad 21.

Game edukasi digital tidak untuk dibedakan dan dibandingkan dengan game tradisional, namun dianggap sebagai kegiatan pedagogis yang memungkinkan anak-anak berinteraksi dan memahami dunia mereka melalui lingkungan digital (Edwards, 2013). Sehingga, bersifat multisensor dan berpusat pada pebelajar, menghubungkan pengetahuan sebelumnya, umpan balik, penilaian diri dan pembelajaran sosial (Oblibger, 2004). Game ini dapat digunakan untuk menerapkan pengetahuan faktual dan mendapatkan pengalaman virtual, sehingga dapat membentuk perilaku, emori, refleksi dan pemahaman karena hasil kombinasi antara pembelajaran dan game (Nikiforidou, 2018). Sifat yang immersive dalam game dapat digunakan untuk membuat pengalaman pengguna sebagai aktor di dalam game. Melalui cara ini anak-anak belajar cara bermain, tampil, mengekspresikan diri, dan berkolaborasi, sehingga paling bisa digunakan untuk menumbuhkan minat belajar dan motivasi (Stephen.,C \& Plowman, 2014). Game Edukasi Digital dapat digunakan sebagai alat yang efektif dalam pembelajaran karena menciptakan motivasi dan kepuasan pribadi, mengakomodasi berbagai macam gaya dan keterampilan belajar, memberikan konteks interaktif dalam memecahkan masalah dan mengedepankan tindakan nyata dari pada hanya penjelasan (Kebritchi, \& Hirumi ;, 2008).

Penerapan game edukasi digital pada anak usia dibawah 7 tahun memiliki pembelajaran yang berbeda, yakni lebih menekankan pada dimensi afektif dan motivasi (Plowman, 2016). Misalnya, mendukung pembelajaran anak-anak dalam membantu penguasan bahasanya dengan menggunakan gesture based-kinect reading game, sehingga memberikan kegiatan yang menarik bagi anak-anak dalam membaca sebuah buku (Hormer., Kinzer., Plass., Loteurneau., Hoffman., Bromley, 2014). Dengan demikian, game edukasi digital penerapannya harus tetap terhubung dengan aktivitas anak-anak, tidak dilihat sebagai kegiatan yang terpisah atau tambahan (Johnson \& Christie, 2009). Secara umum, game edukasi digital memiliki manfaat untuk menumbuhkan ketertarikan pebelajar, mengembangkan keterampilan berfikir, mengembangkan keterampilan komputer, mendukung kebutuhan pebelajar yang beragam dan keterampilan sosial/kolaborasi (Crompton., Lin., Burke., Block, 2017)

\section{METODE}

Penelitian ini bertujuan melakukan literature review dengan mengikuti prosedur literarure review dari Machi dan Mcevoy (Leiter., Khalil.,Ebner, 2017). Enam langkah untuk literature review (Lihat Gambar. 2).

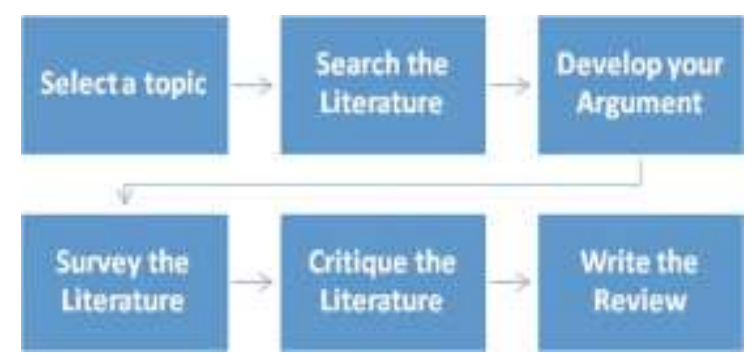

Gambar 2. Enam langkah literature review Machi dan Mcevoy 
42 JINOTEP (Jurnal Inovasi dan Teknologi Pembelajaran): Kajian dan Riset Dalam Teknologi Pembelajaran Vol 6, No. 1, Oktober 2019, Hal. 39-44

Setelah menentukan topik penelitian, selanjutnya mengidentifikasi artikel dari basis data yang sesuai dengan topik permasalahan:

- Artikel berasal dari Association for Computing Machinery (ACM) Digital library

- SpringerLink

- IEEE Xplore Digital Library

Kriteria artikel yang diterima sebagai berikut:

Dalam basis data artikel baik dari ACM, SpringerLink dan IEEE Explorer pencarian menggunakan kata kunci "game based learning", "Digital Game Based Learning" yang ditambahkan dengan "early childhood", "preschool", dan "early years. Khusus dari basis data SpringerLink ditambahkan parameter disiplin "education". Pengumpulan dari basis data menghasilkan 50 artikel publikasi yang sesuai dengan topik penelitian.

Keseluruhan artikel publikasi, dilakukan peninjauan untuk mengambil artikel yang sesuai dengan kriteria yang telah ditentukan. Kriteria tersebut antara lain (a) ditulis dalam bahasa inggris (b) diterbitkan antara tahun 2013 hingga 2018 (c) mengimplementasikan game digital dalam pembelajaran (d) partisipan dalam penelitian berumur di bawah 7 tahun (e) metodologi penelitian menggunakan eksperimen, survei atau mixed method.

Artikel yang memenuhi syarat kriteria total terdapat 31 artikel (ACM: 10, SpringerLink: 14 dan IEEE Explore Digital Library: 7). Tahapan ini, 31 artikel yang telah diterima dianalisis judul, abstrak dan penulisnya. Selanjutnya, artikel tersebut digunakan untuk survei literatur untuk mencari pertanyaan dalam penelitian serta batasan yang disajikan. Peneliti juga menyajikan perkembangan game edukasi digital untuk anak usia dini dari artikel yang telah dipublikasi sejak tahun 2013 hingga 2018.

\section{HASIL}

Jumlah 31 artikel tentang game edukasi digital pada anak usia dini diimplementasikan dalam berbagai konteks pembelajaran yang dikumpulkan dari tahun 2013 hingga 2018.
Gambar 2 menunjukkan statistik frekuensi artikel publikasi tentang game edukasi digital yang digunakan untuk pembelajaran anak usia dini, dengan Frekuensi tertinggi dari SpringerLink disusul dengan ACM dan IEEE Explore Digital Library.

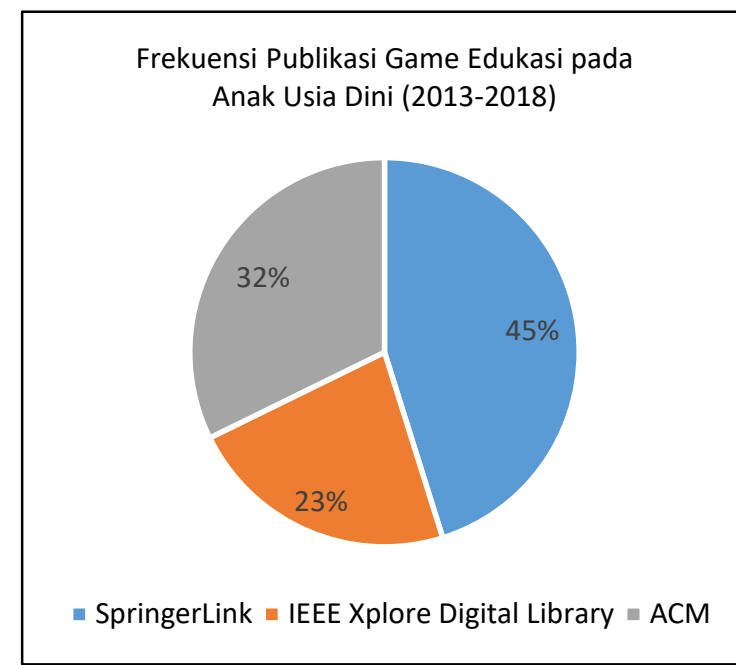

Gambar 2. Frekuensi Publikasi Game Edukasi pada Anak Usia Dini (2013-2018)

Pengenalan kosa kata, keterampilan mengenal angka, mempengaruhi sikap, melatih kinestetik, memperkaya literasi anak, melatih kecerdasan emosional anak, mengembangkan keterampilan dan pengetahuan anak, mengasah keterampilan sosial, semua ini merupakan tujuan penelitian hasil dari survei artikel. Sebagian besar subjek penelitian terdapat di subjek campuran (Lihat Gambar 3). Subjek ini merupakan pengembangan dan penggunaan game edukasi digital tidak hanya bertujuan untuk meningkatkan salah satu domain tertentu, melainkan dalam satu game edukasi digital terdapat beberapa domain keterampilan didalamnya seperti keterampilan berhitung, keterampilan mengenal sesuatu, keterampilan bahasa dan mengembangkan indera. Misalnya penelitian Lamrani yaitu mengembangkan dan mengimplementasikan game edukasi digital dengan pendektan Montessori (Lamrani., Abdelwahed., Chraibi., Qassimi., Hafidi, 2018). Selain itu, matematika juga menjadi perhatian penting, misalnya dalam penelitaian Miller, dengan menggunakan aplikasi game matematika dalam iPad, bertujuan untuk meningkatkan pembelajaran berhitung di taman kanak-kanak 
dan membuat lingkungan pembelajaran interaktif, dengan demikian permainan yang menyenangkan yang didukung dengan lingkungan virtual dapat menumbuhkan domain tertentu seperti berhitung (Miller, 2018).

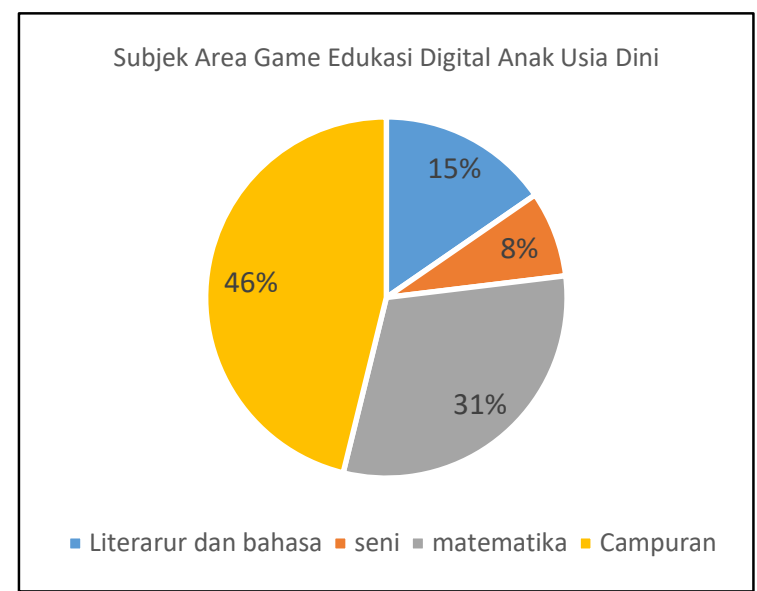

Gambar 3. Subjek Area Game Edukasi Digital Anak Usia Dini

Selanjutnya, statistik metodologi seperti yang ditunjukkan pada gambar 3, menunjukkan bahwa game edukasi digital pada anak usia dini telah dievaluasi baik secara eksperimental, survei dan mixed method. Misalnya, penelitian eksperimen yang dilakukan Akil, Dey, Salian dan Rajput di Kidzee Kindergarten, Bangalore, India yakni sebuah game Edukasi 3D, agar memberikan pembelajaran dengan konteks lingkungan yang lebih realistis untuk mengajarkan nama-nama buah dan sayur yang terdapat disekitar mereka, hasilnya dapat meningkatkan keterlibatan anak-anak dan meningkatkan retensi jangka pendek (Akkil., Dey., Salian., Rajput, 2017). Selanjutnya, penelitian eksperimen yang dilakukan oleh Alzubi, Fernandes, Flores, Duranb dan Cotos di CEIP Ponto dos Brozos, Spanyol mengmbangkan game edukasi digital berbasis interaktif gestur untuk merangsang memori dan keterampilan matematika, hasilnya adalah meningkatkan minat belajar, ketertarikan dan kemampuan matematika (AlZubi., Fernandez., Flores., Duranb., Cotos, 2018). Selain itu penelitian survei juga dilakukan oleh Kalmpourtzis, Vrysis dan Veglis di taman kanak-kanak wilayah Stravoupoli, Thessaloniki, Yunani dengan menyelidiki pelaksanaan, pengorganisasian dan implementasi pembelajaran guna mendesain pembelajaran berbantuan game edukasi digital yang lebih sesusuai untuk memberikan pembelajaran matematika pada anak usia dini (Kalmpourtzis., Vrysis., Veglis, 2016).

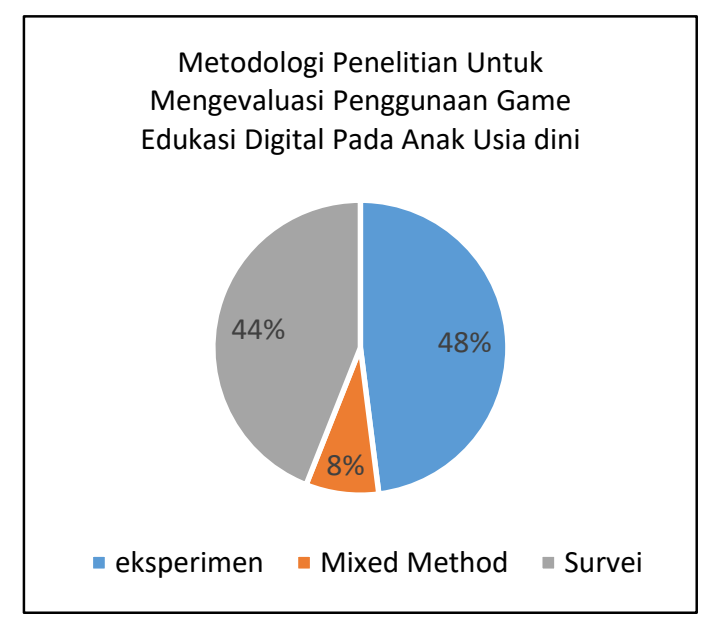

Gambar 3. Metodologi Penelitian Untuk Mengevaluasi Penggunaan Game Edukasi Digital Pada Anak Usia Dini

\section{SIMPULAN}

Inovasi perangkat digital yang cepat juga membawa perubahan dalam menyampaikan pembelajaran, meningkatkan kemampuan pemahaman dan pengetahuan serta penilaian suatau disiplin ilmu yang dikemas dalam game digital. Berbagai aplikasi game edukasi digital telah membawa lingkungan belajar yang menyenangkan, memotivasi, meningkatkan kreativitas, merangsang perkembangan emosional dan mengembangkan psikomotor anak-anak.

Khususnya pembelajaran untuk anak usia dini, lebih cenderung mengeksplorasi afektif dan psikomotornya. Perkembangan game edukasi digital harus mampu diformulasikan untuk mewadahi kebutuhan tersebut. Hadirnya teknologi gesture recognition menjadi jawaban untuk mengembangkan game edukasi digital yang lebih sesuai untuk kebutuhan dan perkembangan anak usia dini. Hal ini terlihat dalam publikasi pada tahun 2017-2018.

Berdasarkan hasil literatur review dari studi yang dilakukan sejak tahun 2013 hingga 2018 area utama adalah mengembangkan game edukasi digital sebagai alat pembelajaran sedangkan penelitian ekserimental dan survei 
44 JINOTEP (Jurnal Inovasi dan Teknologi Pembelajaran): Kajian dan Riset Dalam Teknologi Pembelajaran Vol 6, No. 1, Oktober 2019, Hal. 39-44

menjadi metode penelitian utama yang hampir digunakan pada semua penelitian.

\section{DAFTAR RUJUKAN}

Akman, B., \& Güçhan Özgül, S. (2015). Role of Play in Teaching Science in the Early Childhood Years. Research in Early Childhood Science Education, 237-258. doi:10.1007/978-94017-9505-0_11

AlZubi, T., Fernandez, R., Flores, J., Duranb, M., \& Cotos, M. (2018). Improving the working memory during early childhood education through the use of an interactive gesture game-based learning approach. IEEE Access, 1-1. doi:10.1109/access.2018.2870575

Crompton, H., Lin, Y.-C., Burke, D., \& Block, A. (2017). Mobile Digital Games as an Educational Tool in K-12 Schools. Perspectives on Rethinking and Reforming Education, 3-17. doi:10.1007/978-981-106144-8_1

Edwards, S. (2013). Digital play in the early years: A contextual response to the problem of integrating technologies and play-based pedagogies in the early childhood curriculum. European Early Childhood Education Research Journal, 21(2),199-212. doi.org/10.1080/1350293X.2013.789190.

Homer, B. D., Kinzer, C. K., Plass, J. L., Letourneau, S. M., Hoffman, D., Bromley, M., ... Kornak, Y. (2014). Moved to learn: The effects of interactivity in a Kinect-based literacy game for beginning readers. Computers \& Education, 74,37-49.

doi:10.1016/j.compedu.2014.01.007

Johnson, J., \& Christie, J. (2009). Play and digital media. Computers in the Schools, 26(4),284289. doi.org/10.1080/07380560903360202.

Kalmpourtzis, G., Vrysis, L., \& Veglis, A. (2016). Teaching game design to students of the early childhood through Forest Maths. 2016 11th International Workshop on Semantic and Social Media Adaptation and Personalization (SMAP). doi:10.1109/smap.2016.7753396

Kebritchi, M., \& Hirumi, A. (2008). Examining the pedagogical foundations of modern educationalcomputer games. Computers \& Education, $\quad 51, \quad 1729-1743$. doi.org/10.1016/j.compedu.2008.05.004
Klopfer, E., Osterweil, S., \& Salen, K. (2009). Moving learning games forward: Obstacles, opportunities, and openness. Cambridge, MA: The Education Arcade

Lamrani, R., Abdelwahed, E. H., Chraibi, S., Qassimi, S., \& Hafidi, M. (2018). Gamification and Serious Games Based Learning for Early Childhood in Rural Areas. New Trends in Model and Data Engineering, 79-90. doi:10.1007/978-3-030-02852-7_7

Leitner, P., Khalil, M., \& Ebner, M. (2017). Learning Analytics in Higher Education-A Literature Review. Studies in Systems, Decision and Control, 1-23. doi:10.1007/978-3-319-529776_1

Miller, T. (2018). Developing numeracy skills using interactive technology in a play-based learning environment. International Journal of STEM Education, 5(1). doi:10.1186/s40594-018-0135-2

Nikiforidou, Z. (2018). Digital Games in the Early Childhood Classroom: Theoretical and Practical Considerations. Digital Childhoods, 253-265. doi:10.1007/978-981-10-6484-5_16

Oblinger, D. (2004). The next generation of educational engagement. Journal of Interactive Media in Education, 8, 1-18. doi.org/10.5334/2004-8-oblinger.

Plowman, L. (2016) Learning technology at home and in preschool. Rushby, N., Surry, D. (eds.) Wiley Handbook of Learning Technology, 96-112. Wiley-Blackwell, Malden

Stephen, C., \& Plowman, L. (2014). Digital play. In: Brooker, L., Blaise, M., Edwards, S. (eds.) The Sage Handbook of Play and Learning in Early Childhood Education, 330-341. Sage, Los Angeles/London. 